\title{
Analyses of a surging outlet glacier of Vatnajökull ice cap, Iceland
}

\author{
Guðfinna AĐALGEIRSDÓTTIR, Helgi BJÖRNSSON, Finnur PÁLSSON, \\ Eyjólfur MAGNÚSSON
}

\author{
Science Institute, University of Iceland, Dunhaga 3, IS-107 Reykjavík, Iceland \\ E-mail: g.adalgeirsdottir@swansea.ac.uk
}

\begin{abstract}
Many of the large outlet glaciers of Vatnajökull ice cap, Iceland, have a history of regular surges. The mass transport during surges can be up to $25 \%$ of the total ice flux. This is a considerable amount that affects the whole ice cap, the location of the ice divides, the flow field and the size and shape of the ice cap. Data from the surging outlet Dyngjujökull, on the northern side of Vatnajökull, which surged during the period 1998-2000, are presented: surface elevation changes, displacement and total mass tr ansport. The total gain in ice volume in the receiving area, due to the surge, is considerably smaller than the loss in the reservoir area. The difference is mainly due to enhanced melting rates on the larger surface area of the crevassed glacier surface, and increased turbulent fluxes above the surface, but also due to increased frictional melting at the bed during the surge. A two-dimensional vertically integrated numerical flow model, of standard shallow-ice approximation type, is used to show that a modeled glacier that is similar in size to Dyngjujökull and subject to the same mass balance has three times higher velocities than the measured velocity during the quiescent phase. Adding surges in the numerical model, by periodically increasing the sliding velocity, causes the glacier to retreat and oscillate around a smaller state when subject to the same mass-balance regime. Lowering the equilibrium line by $50 \mathrm{~m}$ lets the modeled surging glacier oscillate around a size similar to that of the present glacier, indicating that surging is an efficient long-term ablation mechanism.
\end{abstract}

\section{INTRODUCTION}

Surges are common on most of the larger ice caps in Iceland. A thorough account of glacier surges in Iceland is given by Björnsson and others (2003). All the broad, large outlet glaciers of Vatnajökull ice cap, on the southeast coast of Iceland, have a history of regular surges. These surges contribute significantly to the total mass transport of the outlet glaciers and affect their size, morphology and flow regime. In this paper, the surge of Dyngjujökull, an outlet glacier on the northwestern side of Vatnajökull, is described and computations with a numerical model are conducted to cast light on the effect of the surge on the flow regime of the glacier.

Dyngjujökull has all the characteristics of a surging glacier as listed by Raymond (1987) and described by Meier and Post (1969). The surges occur repeatedly, with a relatively constant quiescent interval of 20-30years between surges. Documented surges on Dyngjujökull occurred in 1900, 1934, 1951, 1977 and 1999; the intervals between the surges were thus $\sim 34,17,26$ and 22 years. The area affected by surges is $400-800 \mathrm{~km}^{2}$, and generally the terminus advance is about $1.5 \mathrm{~km}$ (Björnsson and others, 2003). The surge phase is $1-2$ years in duration, which is short relative to the quiescent interval. During a surge the surface velocities increase 100-200-fold, and mass is rapidly transported from the up-glacier reservoir area to the downglacier receiving area. During the quiescent period, the surface velocity is lower than the velocity required to maintain the size of the glacier, causing a build-up in the reservoir area and ice loss in the receiving area. Thickness changes during this period gradually return the surface to the pre-surge state.

\section{STUDY AREA AND MEASUREMENTS}

Dyngjujökull is a north-facing, gently sloping outlet glacier of Vatnajökull ice cap (Fig. 1). It is about $40 \mathrm{~km}$ long, $20 \mathrm{~km}$ wide and has an area of $1040 \mathrm{~km}^{2}$. The surface elevation range is $700-1650 \mathrm{~m}$, with an average surface slope of about $1.6^{\circ}$ (Björnsson and others, 2003). The surface and bedrock geometry was surveyed with radio-echo sounding methods in 1989, resulting in a digital elevation model (DEM) with a $200 \mathrm{~m}$ resolution and $2-5 \mathrm{~m}$ accuracy for the surface and 10-30 $\mathrm{m}$ accuracy for the bedrock geometry (Björnsson and others, 1992). The measured surface thus shows the glacier in the middle of a quiescent phase and can be expected to have the relatively flat surface of a retreating glacier.

In a gravity survey effort in the summers of 1997 and 1998, surface elevation measurements were conducted on 40-50 sites on the glacier (Guðmundsson and Högnadóttir, 2001), allowing a new surface map to be created. The change in surface elevation from 1989 to 1998 is shown in Figure 2. During this period the glacier surface lowered considerably in the ablation area, up to $60-70 \mathrm{~m}$ close to the margin, but rose slightly in the accumulation area.

Mass balance and surface velocity have been measured on 10-15 sites on Dyngjujökull since 1993, but during the 1998-2004 period it was not possible to access the survey sites due to the heavily crevassed surface. The location of the sites is shown in Figure 1, and the profile along the glacier length through the survey points together with the massbalance and surface velocity measurements are shown in Figure 3. The equilibrium-line altitude (ELA) varied between 1100 and $1385 \mathrm{~m}$ a.s.l. during the measurement period, 1993-98 (Björnsson and others, 1998). Prior to the surge, the measured surface velocities were only about $25-70 \%$ of the 


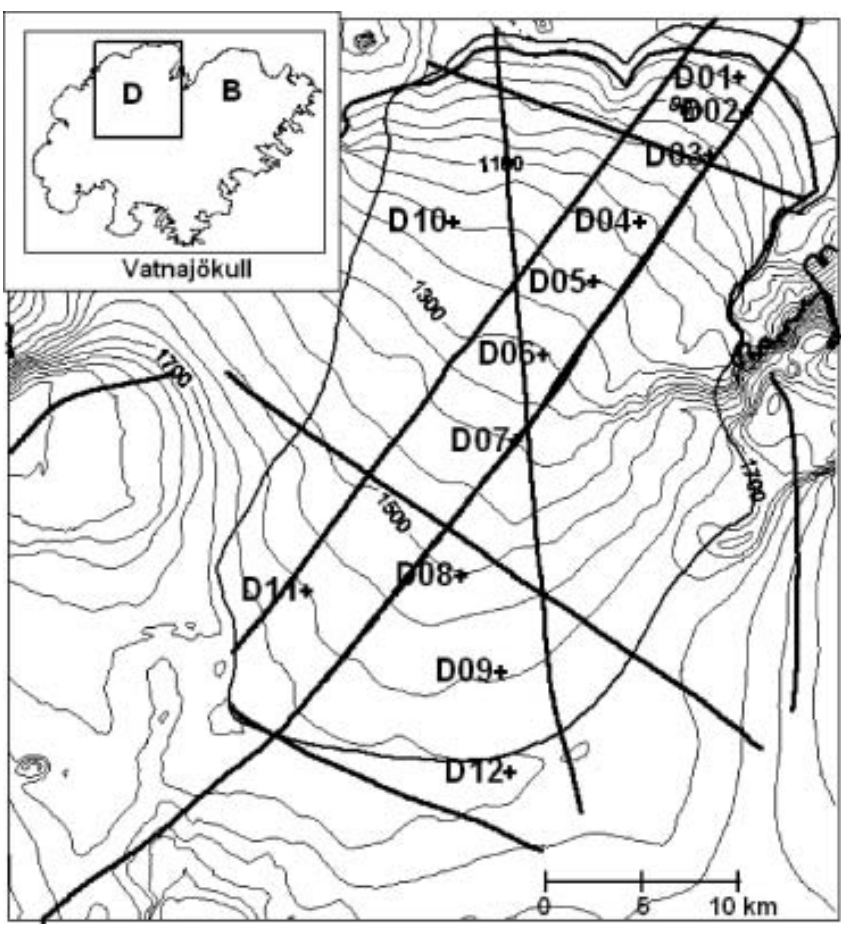

Fig. 1. Contour map of Dyngjujökull. The outline of the glacier which is also the numerical model boundary is delineated. The paths of the airborne radar elevation surveys are shown with thick lines. The path of the January 2000 flight falls onto the September 2000 flight along the measurement sites. The sites of mass-balance and surface velocity measurements are shown with crosses and labeled with corresponding names. The inset map shows Vatnajökull and the outline of the contour map. D and B refer to Dyngjujökull and Brúarjökull, respectively.

balance velocities (Björnsson and others, 1995a, b, 1997). Meltwater from Dyngjujökull is the largest source for the river Jökulsá á Fjöllum which has a discharge of about $50 \mathrm{~m}^{3} \mathrm{~s}^{-1}$ in winter, increasing to $200-300 \mathrm{~m}^{3} \mathrm{~s}^{-1}$ in summer (personal communication from H. Haraldsson, 2000). Sigurðsson (1990) showed with chemical analysis of the groundwater that water originating from glaciers is present in shallow aquifers, bordering on or extending under the glaciers. He also notes that the drainage basin of Jökulsá á Fjöllum is situated on a permeable young rock formation (mostly Late Quaternary to Recent) and has considerably higher winter discharge than the neighboring river Jökulsá á Brú $\left(\sim 5-10 \mathrm{~m}^{3} \mathrm{~s}^{-1}\right)$, which drains Brúarjökull, the northeast outlet of Vatnajökull, and is situated on an impermeable formation (mostly Tertiary and Early Quaternary), while the summer discharge of these two rivers is similar. This difference indicates an active groundwater system in the drainage basin of Jökulsá á Fjöllum and the possibility of groundwater infiltration beneath Dyngjujökull. Flowers and others (2003) showed with a numerical glacio-hydraulic model that, of all the outlet glaciers of Vatnajökull, Dyngjujökull exhibits the highest sensitivities to geothermally derived meltwater, subsurface groundwater loss and surface snowmelt routing.

\section{SURGE IN DYNGJUJÖKULL, 1998-2000}

The first indicator of the surge was increased sliding velocity at sites D05, D07 and D09 during summer 1996. A year

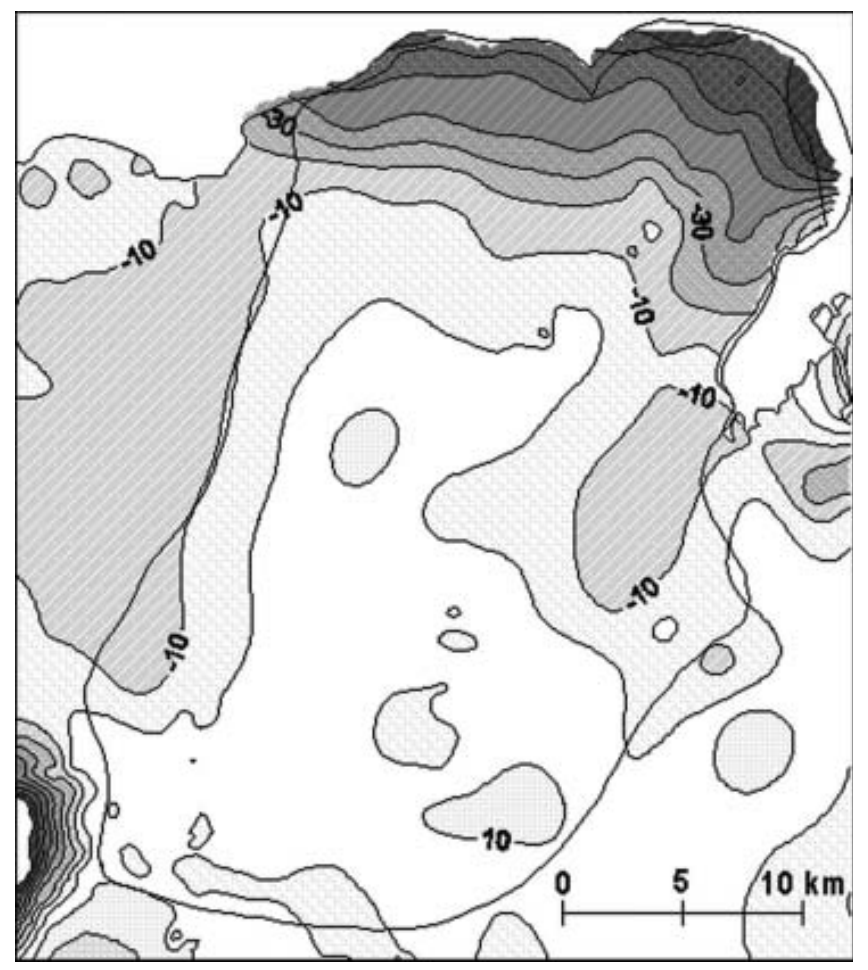

Fig. 2. Difference in surface elevation $(m)$ from the time of the radio-echo sounding survey in 1989 to the gravity survey in 1998, at the beginning of the surge. The surface lowered by up to $70 \mathrm{~m}$ close to the terminus, but rose slightly in the accumulation area.

later, a significant velocity increase was measured at sites D03 and D07 (no data for D05). In the autumn, unusual crevasses were observed between sites D07 and D05. In summer 1998, the velocity increased considerably at D03 (from about $10 \mathrm{~m} \mathrm{a}^{-1}$ to $23 \mathrm{~m} \mathrm{a}^{-1}$ ) and tripled at sites D05 (from about 40-50 $\mathrm{m} \mathrm{a}^{-1}$ to $137 \mathrm{~m} \mathrm{a}^{-1}$ ) and D07 (from about 50-70 $\mathrm{m} \mathrm{a}^{-1}$ to $143 \mathrm{~m} \mathrm{a}^{-1}$ ), between which the ELA normally lies (Fig. 3). In the autumn, long crevasses, following altitude contours (tens of $\mathrm{cm}$ up to $1.5 \mathrm{~m}$ wide), were observed in a $1 \mathrm{~km}$ wide area around site D07, and new crevasses were open close to site D05. In spring 1999, the crevassed belt had extended much higher up-glacier and open and clearly active crevasses were spotted $2.5 \mathrm{~km}$ south of D09. During the period 1998-2004 no direct velocity or mass-balance measurements were carried out on the glacier due to the heavily crevassed surface after the surge. In a reconnaissance flight on 18 August 1999 the outline of the surgeaffected area was located. A visible bulge on the surface was clearly observed at an elevation of about 1000-1100 m. On 20 September 1999, when site D11 was measured, extension crevasses were clearly seen in its neighborhood. In a flight over the glacier on 8 November 1999 the visibility was poor, but it seemed that the surge front had only reached the glacier margin on the western side of the surge area. In another flight on 15 November 1999 it was seen that the surge wave had reached the margin everywhere. On 27 January 2000 an airborne radar elevation survey was conducted along a line that approximately follows sites D01, D02, D03, D05 and D07. Another, more extensive radar elevation survey was carried out on 14 September 2000, when five survey lines across the surge area, one following the survey line from January, were flown. These survey data allowed a difference map between the data and 

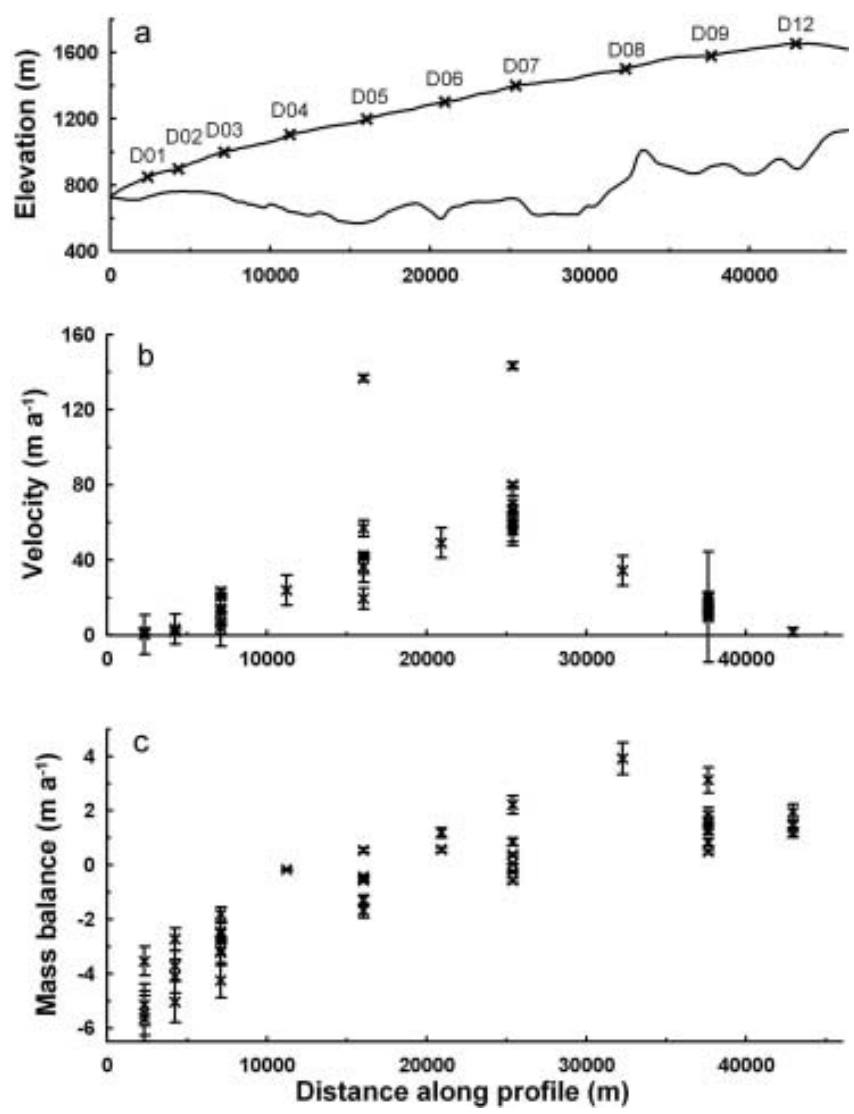

Fig. 3. Profile along the measurement sites shown in Figure 1. (a) Surface and bedrock elevation, along with the location of massbalance and surface velocity measurements; (b) surface velocity measurements at each site, 1993-98; and (c) the mass-balance measurements at the same sites.

the surface map from 1998 to be created. This difference map (Fig. 4) provides a fair estimate for the surface of Dyngjujökull at the end of 2000. It appears that during the surge an elevation drop of up to $70 \mathrm{~m}$ occurred in the reservoir area and the surface rose by up to $100 \mathrm{~m}$ near the glacier margin. No attempt was made to estimate the surface changes outside the surge area. Therefore the surface maps from 1998 and 2000 are the same outside that area.

This surge was also observed using European Remotesensing Satellite (ERS) synthetic aperture radar (SAR) tandem interferograms (Fischer and others, 2003). There are interferograms available from before the surge start and three during the surge. Between March 1996 and January 1997, surface velocity acceleration was observed in an area of $200 \mathrm{~km}^{2}$ near the ELA. In an interferogram from 6/7 January 1999 a well-developed $210 \mathrm{~km}^{2}$ surge area is observed, which increased to $250 \mathrm{~km}^{2}$ by $10 / 11$ February 1999 . The third interferogram, from $26 / 27$ January 2000 , shows an area of $550 \mathrm{~km}^{2}$ affected by the surge. In the interferograms of January and February 1999 the maximum velocity is located near the ELA, but in the January 2000 interferogram it is located near the snout. In this sequence of interferograms, a southward migration of the area with very low or no flow at the head of the glacier, indicating the location of the ice divide, is observed. The location of the ice divide cannot be determined from these images, but the southward migration of the no-flow area during the surge would increase the accumulation area (Fischer and others, 2003).

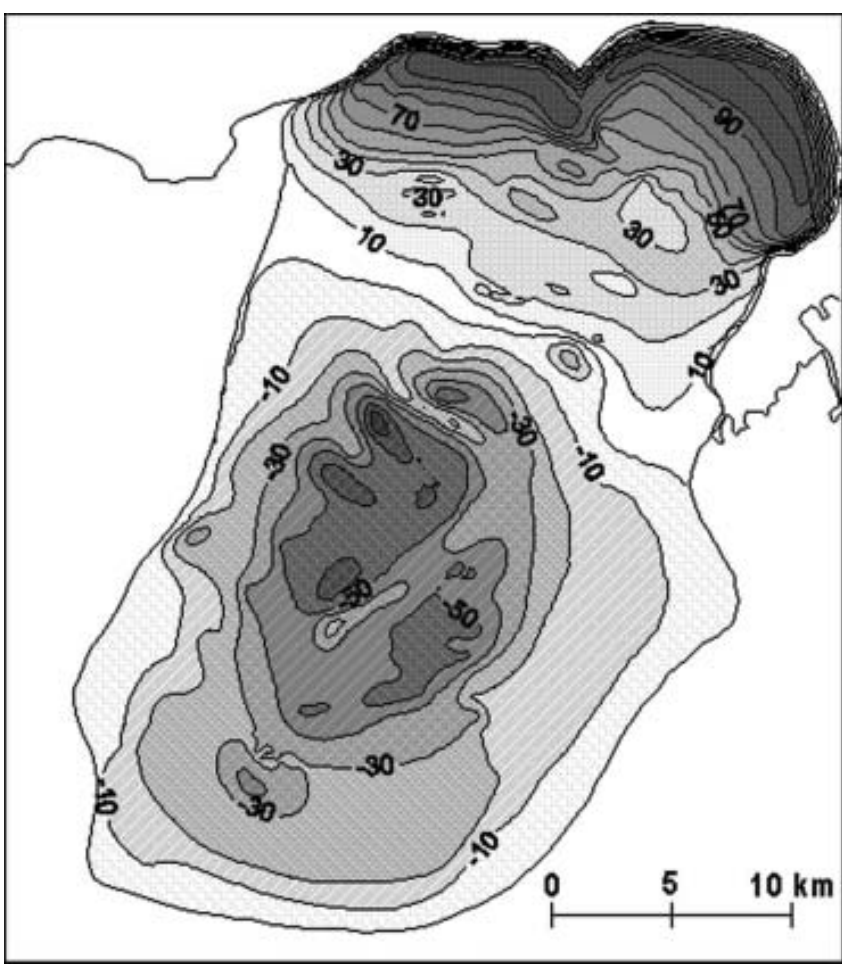

Fig. 4. Difference in surface elevation (m) from 1998 to September 2000. The reservoir area lowered by up to $70 \mathrm{~m}$ and the receiving area rose by up to $100 \mathrm{~m}$ near the margin.

An attempt was made to retrieve the surface velocity with a speckle-tracking method. In the surging area, this was not possible due to decorrelation caused by high deformation rates, but surface velocities of up to $7 \mathrm{~m} \mathrm{~d}^{-1}$ were measured outside the highly deformed areas (Fischer and others, 2003). By using mass continuity to provide the connection between the displacement and the ice-thickness change, an estimate for the displacement during the surge, the mass transport and velocity was made by comparing the surface maps from 1998 and 2000 (Pálsson and others, 2002). The glacier is assumed to move as a block, which is reasonable in a surge. The horizontal displacement along the profile from September 1998 to September 2000 increases from the head of the glacier to approximately the ELA at $20 \mathrm{~km}$ downglacier, where it reaches a value of approximately $1800 \mathrm{~m}$. The displacement is close to this value until $30 \mathrm{~km}$ downglacier, at the boundary between the reservoir and receiving area, and then increases towards the margin to $2600 \mathrm{~m}$. At the margin the accumulated displacement is close to $2 \mathrm{~km}$. This is in agreement with an independent estimate of $1.9 \mathrm{~km}$ made by assuming that the shape of the margin is similar to 1989 and examining margin surface slopes and surface-bed crossover points from the airborne radar survey in 2000 (Pálsson and others, 2002). This displacement estimate gives an average velocity of $2.7-3.5 \mathrm{~m} \mathrm{~d}^{-1}$ for the period $1998-$ 2000, which includes a period when the glacier was not surging. The flights in August and November 1999 that located the surge wave, and the radar surveys in January and September 2000 allow the maximum velocity in the surge to be estimated as at least $42 \mathrm{md}^{-1}$. This is thought to be a conservative estimate since it is an average over an elevation contour and the timing of the surge termination is not well constrained. 

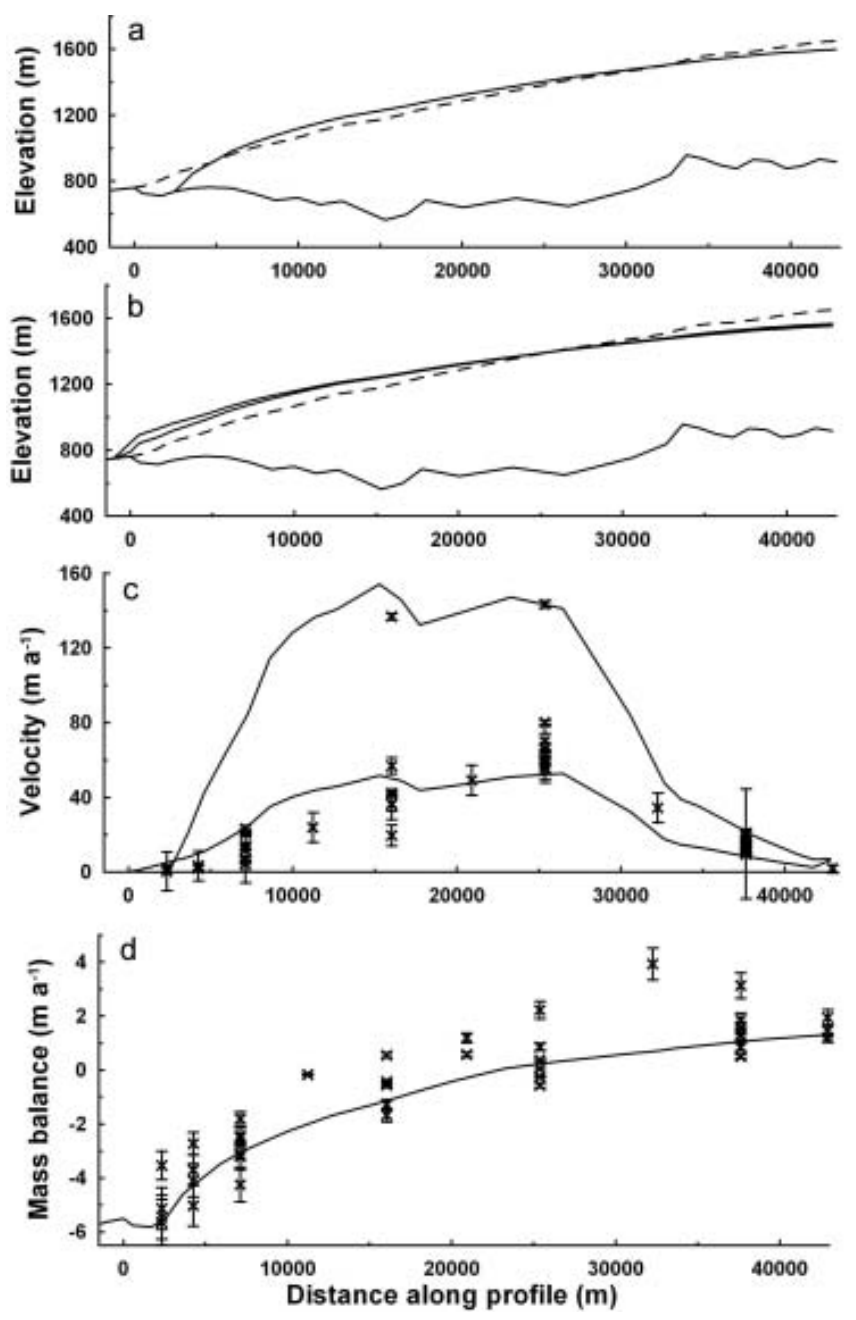

Fig. 5. Model results. (a) The steady-state numerical glacier which is similar in size to the measured glacier, shown with a dotted line. (b) The profile of the surging glacier just before a surge and just after a surge. The measured surface is shown with a dotted line. (c) The modeled deformation velocity and the balance velocity (deformation plus sliding velocity) for the steady-state glacier. Measured surface velocity is shown for comparison. (d) The modeled mass balance for the reference ELA; the measured mass balance is shown for comparison.

By integrating the difference map shown in Figure 4, the volume change of the surging area within the glacier can be estimated. A mass loss of $13.0 \mathrm{~km}^{3}$ in the reservoir area, but a gain of $9.8 \mathrm{~km}^{3}$ in the receiving area, is computed. Uncertainty in these volume estimates, due to possible bias in the radar data of $\pm 2 \mathrm{~m}$, is $1.6 \mathrm{~km}^{3}$. The difference is due to enhanced melt rates during the surge period as discussed below. An estimate for the mass transport from January to September 2000 finds that $1.5 \mathrm{~km}^{3}$ of ice was transported through the surge equilibrium-line cross-section. This is about $10 \%$ of the total mass transport, indicating that the surge was nearly finished before January 2000.

\section{NUMERICAL FLOW MODEL}

A numerical flow model is applied to the outlet glacier Dyngjujökull to analyze the effect of the surge on the flow regime and the size of the glacier. This is a two-dimensional, standard shallow-ice approximation (SIA) model (Hutter, 1983). The constitutive equation for the ice is Glen's flow law (Glen, 1955), and sliding at the bed is approximated using a Weertman-type sliding law (Paterson, 1994). This model uses the alternating direction semi-implicit (ADS-I) finite-difference scheme (Huybrechts, 1986) to solve the continuity equation on a $1 \mathrm{~km}$ grid, and has been adapted for use on Vatnajökull (Aðalgeirsdóttir, 2003). The massbalance distribution is computed from a parameterization of the available mass-balance measurements that uses the ELA as an independent variable to determine the net balance (Aðalgeirsdóttir and others, 2003). Dyngjujökull is separated from the rest of the ice cap by applying a no-flow boundary condition at the ice divide, thus fixing the ice divide at the same location, but allowing the surface elevation to change freely. This may not be a realistic boundary condition during a surge; it has been observed that the ice divide migrated during the surge in 1999 (Fischer and others, 2003). It is, however, not thought to have a significant effect on the modeling results presented here as the lowering of the surface during the surge will counteract the increased accumulation area.

The rate factor in Glen's flow law in all the model experiments is the value recommended for temperate ice ( $A=6.8 \times 10^{-15} \mathrm{~s}^{-1} \mathrm{kPa}^{-3}$; Paterson, 1994). Sliding at the bed and the ELA are the two model parameters that are adjusted until the corresponding steady-state geometry leads to a good fit to the measured surface geometry. The resulting sliding parameter is $C=58 \times 10^{-15} \mathrm{~m} \mathrm{a}^{-1} \mathrm{~Pa}^{-3}$, similar to the value obtained in a study for the whole ice cap (Aðalgeirsdóttir, 2003), and the resulting ELA will hereafter be referred to as the reference $\operatorname{ELA}(\triangle \mathrm{ELA}=0)$. The resulting steady-state surface profile, at the same location as the profile in Figure 3, is shown in Figure 5, as well as the modeled deformation velocity, the total velocity (deformation plus sliding) and the mass balance. A comparison with the measured surface profile (dashed line in Fig. 5a) shows that the modeled profile is slightly thicker in the lower part, thinner in the upper part and the terminus of the modeled glacier is steeper. This indicates that the mass transport from the upper to the lower part is more efficient in the model than for the measured glacier. The comparison of the modeled velocity with the measurements confirms this. The modeled velocity, which is the balance velocity for the corresponding surface geometry, is about three times higher than the measured velocity before the onset of the surge. The velocities measured at D05 and D07 in summer 1998, at the beginning of the surge, are similar to the modeled velocity. The modeled deformation velocity is within the range given by the velocity measurements. The modeled mass balance is similar to the measured mass balance.

Sensitivity tests show that small changes in the ELA, that are within the elevation range given by the measurements, cause the glacier to start to advance northwards and thicken, or retreat and thin. The volume evolution of the ice cap for the sensitivity tests is shown in Figure 6a. Thickening or thinning of this outlet glacier would influence the whole ice cap, but because of the fixed ice divide in the model this influence is not taken into account. This model cannot therefore produce other realistic steady states within the measured mass-balance regime.

Model runs that imitate surges were conducted. No sliding was allowed in the quiescent phase, so the modeled velocity was similar to the measured velocity. Then repeatedly, every 30 years, for a period of one model year the model was run with a 100-fold sliding parameter from 
the previous model experiment, representing surge cycles. The resulting volume evolution during the model runs with different values for the ELA is shown in Figure 6b. With the same value of the ELA as before $(\triangle E L A=0)$, the volume of the surging outlet glacier reduces by more than half within 1000 years. If the ELA is lowered, and thereby the accumulation area increased, the retreat is slowed. With a $50 \mathrm{~m}$ lower ELA than in the no-surge experiment, the outlet glacier oscillates around a volume similar to that of the present glacier. The surface profiles of this surging glacier, just before and just after a surge, are shown in Figure $5 \mathrm{~b}$. The surging outlet glacier is thicker than the measured glacier in the ablation area and thinner in the accumulation area. This indicates more mass transport than observed. In each modeled surge, the volume of ice transported is about $21 \mathrm{~km}^{3}$. This is more than observed in the 1999 surge. In the model the sliding is increased over the whole area simultaneously, while in reality the area affected by the surge gradually increases, so the difference is not unexpected. The effect of the surge is, however, the same. By lowering the ELA further, the surging outlet glacier grows, but approaches a steady state. The repeated surges shrink the glacier and decrease the sensitivity to perturbations in the ELA. This is analogous to the result obtained with a flowline model, which showed that surges cause glaciers, subject to the same accumulation as non-surging glaciers, to be smaller on average (Gudmundsson and others, 2003). The redistribution of the mass from the accumulation area to the ablation area during surges is more efficient in promoting ablation than the effect of the lowered ELA that causes the glacier to grow when no surges occur.

\section{DISCUSSION AND CONCLUSION}

The 1998-2000 surge of Dyngjujökull caused a drop of up to $70 \mathrm{~m}$ in elevation in the reservoir area and a thickening of up to $100 \mathrm{~m}$ close to the margin. The terminus advanced up to $1.9 \mathrm{~km}$ in the eastern part but less in the western part. The total volume of ice transported from the reservoir area to the receiving area, through the surge equilibrium line, was about $13 \mathrm{~km}^{3}$. This caused $>1.5 \mathrm{~km}$ average horizontal displacement. The velocity of the glacier probably exceeded $40 \mathrm{~m} \mathrm{~d}^{-1}$ at the surge wave front in autumn 1999. The ice volume transported to the receiving area is only about threequarters of the mass lost in the reservoir area, according to the integration over the difference map from 1998-2000 (Fig. 4). Possible reasons for this difference could be:

1. additional melt due to friction at the bed during the surge;

2. enhanced melt rates due to changed elevation distribution;

3. increased surface area subject to melt after the surface was broken up with crevasses, and

4. enhanced turbulent fluxes over the rougher surface, causing increased melting.

Reasons (3) and (4) are difficult to quantify, but we can estimate the effect of (1) and (2). The amount of additional melt due to change in elevation distribution is estimated to be $0.15 \mathrm{~km}^{3}$ (Pálsson and others, 2002). The elevation distribution will gradually change and be similar to that of 1998 in two to three decades. Assuming that all the change
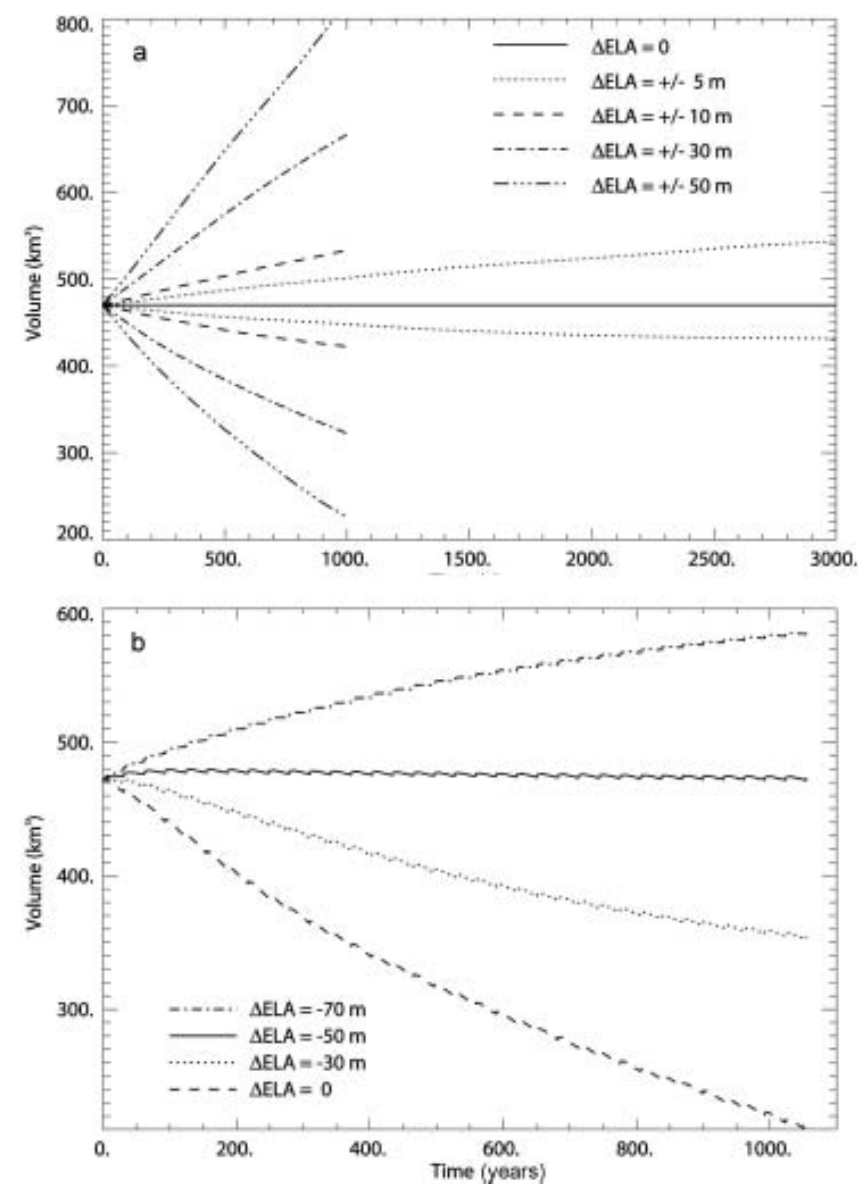

Fig. 6. Volume evolution during the model experiments. (a) Sensitivity to the ELA. Small changes in the ELA cause the glacier volume to increase or decrease. (b) Volume evolution during the surge experiment. Model run with the reference ELA and periodic surges shows a vanishing glacier. By lowering the ELA by $50 \mathrm{~m}$, the modeled glacier oscillates around a volume similar to the steadystate volume.

in potential energy during the surge is used to melt ice at the bed, this would give ice loss of about $0.2 \mathrm{~km}^{3}$. No direct mass-balance measurements are available, but an estimate for normal surface conditions of $-0.5 \mathrm{~km}^{3}$ for the total mass balance this year was made by comparing the neighboring glaciers and the relation between the glaciers in previous years (Pálsson and others, 2002). The remaining volume of ice, $2.3 \pm 1.6 \mathrm{~km}^{3}$, that is not accounted for in the difference between the ice lost in the reservoir area and gained in the receiving area, is probably due to enhanced melting of the crevassed surface. On a hydrograph provided by the Icelandic National Power Company (personal communication from $\mathrm{H}$. Haraldsson, 2000), an increase of about $30 \%$ in the annual runoff in the river Jökulsá á Fjöllum is observed. The summer average discharge originating from the glacier increased from approximately $120 \mathrm{~m}^{3} \mathrm{~s}^{-1}$ to $270 \mathrm{~m}^{3} \mathrm{~s}^{-1}$ in the year 2000 . This increase amounts to roughly $1.5 \mathrm{~km}^{3}$ over the summer. The drainage basin is situated on a permeable rock formation, so some of the additional meltwater may have filtered to the groundwater and therefore not be visible in the hydrograph. Groundwater of glacial origin has been found in the groundwater system stretching more than $10 \mathrm{~km}$ away from the glacier (Sigurðsson, 1990).

The model experiments show that a glacier similar in size, and subject to similar mass balance, flows about three times 
faster than the measured surface velocity of Dyngjujökull during the quiescent phase. This difference clearly expresses the surge nature of Dyngjujökull.

Surges were forced in the model by periodically increasing the sliding parameter during one model year. The result of this model experiment shows that repeated surges are efficient in displacing mass to the ablation area, causing surging glaciers to be smaller than non-surging glaciers subject to the same mass-balance distribution.

\section{ACKNOWLEDGEMENTS}

We thank M.T.Guðmundsson, P. Högnadóttir and H. Gíslason for the global positioning system survey points on Dyngjujökull in 1998. M.T. Guðmundsson carried out the airborne radar elevation survey in January and September 2000. This work was supported by the National Power Company (Landsvirkjun), the National Research Council of Iceland, the Nordic Energy Research of the Nordic Council of Ministers, and the National Energy Fund of Iceland. Comments by T. Jóhannesson and two anonymous reviewers are gratefully acknowledged.

\section{REFERENCES}

Aðalgeirsdóttir, G. 2003. Flow dynamics of the Vatnajökull ice cap, Iceland. Eidg. Tech. Hochschule, Zürich. Versuchsanst. Wasserbau, Hydrol. Glaziol. Mitt. 181.

Aðalgeirsdóttir, G., G.H. Guðmundsson and H. Björnsson. 2003. A regression model for the mass-balance distribution of the Vatnajökull ice cap, Iceland. Ann. Glaciol., 37, 189-193.

Björnsson, H., F. Pálsson and M.T. Guðmundsson. 1992. Vatnajökull, northwestern part: ice surface and bedrock maps. Reykjavík, University of Iceland. National Power Company and Science Institute. (Scale $1: 100000$.)

Björnsson, H., F. Pálsson and M.T. Guðmundsson. 1995a. Afkoma, hreyfing og afrennsli á vestan- og norðanverðum Vatnajökli jökulárin 1992-1993 og 1993-1994. Reykjavík, Raunvísindastofnun Háskólans. (Technical Reports RH-95-2.)

Björnsson, H., F. Pálsson and M.T. Guðmundsson. 1995b. Afkoma, hreyfing og afrennsli á vestan- og norðanverðum Vatnajökli jökulárin 1994-1995. Reykjavík, Raunvísindastofnun Háskólans. (Technical Reports RH-95-25.)
Björnsson, H., F. Pálsson, M.T. Guðmundsson and H.H. Haraldsson. 1997. Afkoma, Hreyfing og afrennsli á vestan- og norðanverðum Vatnajökli jökulárið 1995-1996. Reykjavík, Raunvísindastofnun Háskólans. (Report RH-24-97.)

Björnsson, H., F. Pálsson, M.T. Guðmundsson and H.H. Haraldsson. 1998. Mass balance of western and northern Vatnajökull, Iceland, 1991-1995. Jökull, 45, 35-58.

Björnsson, H., F. Pálssonm O. Sigurðsson and G.E. Flowers. 2003. Surges of glaciers in Iceland. Ann. Glaciol., 36, 82-90.

Fischer, A., H. Rott and H. Björnsson. 2003. Observation of recent surges of Vatnajökull, Iceland, by means of ERS SAR interferometry. Ann. Glaciol., 37, 69-76.

Flowers, G.E., H. Björnsson and F. Pálsson. 2003. New insights into the subglacial and periglacial hydrology of Vatnajökull, Iceland, from a distributed physical model. J. Glaciol., 49(165), 257-270.

Glen, J.W. 1955. The creep of polycrystalline ice. Proc. R. Soc. London, Ser. A, 228(1175), 519-538.

Guðmundsson, M.T. and T. Högnadóttir. 2001. Gravity surveying 1988-2001: central volcanoes in the eastern volcanic zone and hyaloclastite regions in the western volcanic zone. Reykjavík, Raunvísindastofnun Háskólans. (Report RH-22-2001.)

Gudmundsson, G.H., G. Aðalgeirsðóttir and H. Björnsson. 2003. Observational verification of predicted increase in bedrock-tosurface amplitude transfer during a glacier surge. Ann. Glaciol., 36, 91-96.

Hutter, K. 1983. Theoretical glaciology; material science of ice and the mechanics of glaciers and ice sheets. Dordrecht, etc., D. Reidel Publishing Co./Tokyo, Terra Scientific Publishing.

Huybrechts, P. 1986. A three-dimensional time-dependent numerical model for polar ice sheets: some basic testing with a stable and efficient finite difference scheme. Brussels, Vrije Universiteit. Geografisch Institut. (Report 86/1.)

Meier, M.F. and A. Post. 1969. What are glacier surges? Can. J. Earth Sci., 6(4), 807-817.

Pálsson, F., E. Magnusson and H. Björnsson. 2002. The surge of Dyngjujökull 1997-2000: mass transport, ice flow velocities, and effects on mass balance and runoff. Reykjavík, Raunvísindastofnun Háskólans. (Report RH-01-2001.)

Paterson, W.S.B. 1994. The physics of glaciers. Third edition. Oxford, etc., Elsevier.

Raymond, C.F. 1987. How do glaciers surge? A review. J. Geophys. Res., 92(B9), 9121-9134.

Sigurðsson, F. 1990. Groundwater from glacial areas in Iceland. Jökull, 40, 119-146. 